\title{
Den verdifulle barneidretten - da og nå
}

Det nærmer seg påske, og mange vil spenne på seg skiene og kjenne gleden avå være i aktivitet, uten nødvendigvis å konkurrere. I Tidsskriftet nr. 13-14 i 1938 er man opptatt av at idrettskonkurransene for barn skal være så jevne som mulig (Tidsskr Nor Lægeforen 1938; 58: 786-94). På grunnlag av undersøkelser mente man derfor at barn burde konkurrere mot andre barn som var likt fysisk utviklet, uavhengig av alder og årsklasser. I dag er man opptatt av egenverdien til barneidretten og forsøker å utvikle potensialet hos alle, fremfor å lete etter talentene. Erfaringsmessig er nemlig de «beste» født tidlig på året og har kommet lengst i fysisk og motorisk utvikling på sitt årskull. Enigheten er altså bred - da og nå.

\section{Konkurranseidrett for barn og «fysisk alder».}

Av Arne Bruusgaard, Oslo.

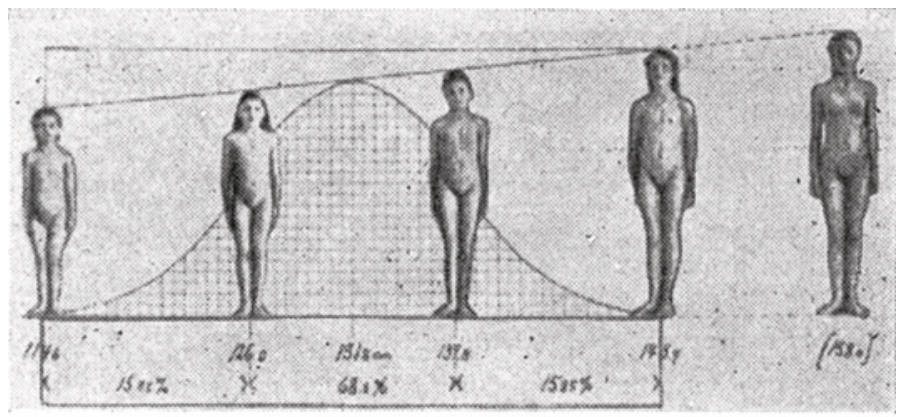

Fig. 1.

For oss idrettslæger har denne økende aktiviteten fra barnedeltagernes side skapt spesielle problemer av stor viktighet. Vi vet på den ene siden hvor betydningsfullt det er for barns fysiske utvikling at de får anledning til å drive fornuftige legemsøvelser avpasset efter hver enkelts alders- og utviklingstrin. På den annen side vet vi hvor uheldig idretten kan virke hvis barnets uhemmede ærgjerrighet får råde uten nogen kontroll og begrensning. Man må her særlig være opmerksom på den fare som ligger i muligheten for overanstrengelser. Ikke minst gjelder dette ved konkurranser. For all sund konkurranseidrett er det derfor om å gjøre å finne frem til en klasseinndeling som kan gi hver og en sin plass, hvor den enkelte med sine spesielle forutsetninger kan finne en passende konkurranse som virker sundt stimulerende, uten fare for skadelige følger. Behovet for en slik klasseinndeling er størst nettop i barneårene hvor aldersforskjellen og de store variasjoner $\mathrm{i}$ vekstutviklingen skaper så ytterst ulike forutsetninger. (...)

Noget bedre vilde forholdene bli om hver klasse av konkurrenter bare omfattet en enkelt årsklasse; men allerede her er forskjellen så stor at det ikke gir grunnlag for nogen rettferdig konkurranse. Denne forskjell fremgår tydelig av figur 1 som skjematisk viser høidevariasjonen hos 12-års piker.

$\AA$ A bruke skoleklasser som utgangspunkt er selvfølgelig helt ubiologisk, en enkelt klasse kan jo omfatte $2-3$, ja op til 4 forskjellige aldersklasser.

Først når man innen hver konkurranseklasse bare plaserer dem som har nogenlunde samme fysiske utvikling, skaper man det rette grunnlag for en sund og rettferdig konkurranse. (...)

Den fysiske alders prinsipp er skapt på grunnlag av massemålinger av Oslo skolebarns høide- og vektforhold og idrettsprestasjoner (...).

At idrettspresentasjonene hos barn stiger med økende alder har man lenge visst; men resultatene av disse undersøkelser var at både barns høide og vekt var av noesten like stor betydning for idrettspresentasjonene. 